\title{
Earnings Management Index, State Ownership, Industrial Sectors, and Timeliness of Financial Report In Indonesia
}

\author{
Shindy Anisa Putri ${ }^{1 . a}$, Y. Anni Aryani ${ }^{1 . b^{*}}$ \\ ${ }^{1}$ Accounting Departement, Faculty of Economics and Business, Universitas Sebelas Maret \\ Jl. Ir Sutami No.36A, Jebres, Kec. Jebres, Kota Surakarta, Jawa Tengah 57126 \\ e-mail: aanisashindyy@gmail.com, by_anniaryani@staff.uns.ac.id \\ * Corresponding Author
}

\begin{abstract}
In recent years, IDX reported that a high number of enterprises' financial reporting were overdue. Timeliness of financial report is necessary since it is used as the main source of information. This paper aims to investigate several factors affecting timeliness of financial report in Indonesia. Using the purposive sampling technique, this study gained 318 enterprises listed on IDX during 2015 until 2017. The result showed that earnings management index and industrial sector were significantly related to the timeliness of financial report. On the other hand, state ownership do not have significant relation with the timeliness of financial report.
\end{abstract}

Keywords: Earnings Management Index, Industrial Sector, State Ownership, Timeliness

Article History: Received: February, 212020 Revised: August, 242020 Accepted: October, 92020

How to cite: Putri, S.A., \& Aryani, Y.A. (2020). Earnings Management Index, State Ownership, Industrial Sectors, And Timeliness Of Financial Report In Indonesia. Akrual: Jurnal Akuntansi, 11(2):53-65. DOI: https://doi.org/10.26740/jaj.v11n2.p53-65.

\section{INTRODUCTION}

As one of the company's fundamental information sources, financial reports are needed by various parties to make a decision. Accounting information in financial statements needs to meet qualitative characteristics based on the Statement of Financial Accounting Concepts (SFAC) No. 8 chapter three of 2010 which consists of aspects of relevance and representation appropriately. These aspects are needed to minimize information asymmetry that can cause errors in decision-making. Financial information needs to be delivered in a timely manner (timeliness) to be able to influence user decisions. Thus, the longer the reporting is carried out, the less useful the information is in the financial statements.

Based on the information available, Indonesia Stock Exchange (IDX) noted that in May 2016 there were 63 companies that had not submitted their audited financial reports as of 31 December 2015 (http://bisnis.liputan6.com). Furthermore, in July 2017 there were 17 companies that had not submitted their audited financial reports as of December 312016 (https://finance.detik.com) and in July 2018 there were ten companies that had not submitted their audited financial reports as of December 31, 2017 (https: //www.cnbcindonesia.com). 
The company is rumored to have received sanctions in the form of a suspension of stock market trading as well as a fine with a certain nominal value. Related to this, Indonesia Financial Service Authority (OJK) has set a regulation on the deadline for submitting audited financial statements for all companies listed on the IDX. According to the Regulation of Indonesia Financial Authority (POJK) Number 29/POJK.04/ 2016, the deadline for submitting the issuer's financial statements is at the end of the fourth month after the book closing period.

The existence of regulations related to financial reporting, both in general by the Financial Accounting Standard Boards (FASB) and independently by each country, proves that the timeliness of financial statements is important for every company. The company needs to maintain the qualitative characteristics of financial information so as not to cause errors in decision making that can harm stakeholders. As a party that is obliged to submit financial statements, the company needs to pay attention to various factors that can lead to delays in the submission of financial statements. Company accountants are expected to be able to present financial reports optimally to minimize the occurrence of bias in accounting information and fraud in financial statements. In addition, companies need to comply with regulations related to the deadline for submitting financial statements to avoid losses from sanctions imposed by authorized institutions.

Various studies related to factors that influence the timeliness of financial statements have been carried out previously, namely by Suharli and Harahap (2008); Khasharmeh and Aljifri (2010); Lie (2012); Pratama and Adiwibowo (2014); Clatworthy and Peel (2016); Ghafran and Yasmin (2017); Abernathy, Kubick, and Masli (2018); and Ha, Hung, and Phuong (2018). Previous research proves that financial performance, such as profitability (Suharli and Harahap, 2008; Ha et al., 2018), debt ratios (Khasharmeh and Aljifri, 2010), and leverage (Lie, 2012), is one factor that can affect reporting finance. Financial performance is an indicator that can be used as a detector for fraud (Wells, 2001). In addition, financial performance is a component of the measurement of earnings management developed by Serrano-Cinca, Gutierrez-Neito, and Bernate-Valbuena (2018). Earnings management index is a model that is formed to determine the real earnings management activities in a company. Permatasari (2005) states that earnings management activities measured by discretionary accruals can slow down the submission of financial statements. However, the use of accrual methods in earnings management activities has a limited degree of flexibility. In addition, Ajina, Laouiti, and Msolli (2016) prove that earnings management activities can also result in low readability in financial statements, allowing errors in interpretation of financial performance.

The timeliness of financial statements can also be influenced by various nonfinancial factors. According to the review of the literature, the industrial sector is one of the factors that can influence the timeliness of financial statements. Khasharmeh and Aljifri (2010) state that the industrial sector has a significant influence on the timeliness of financial statements in Bahrain. However, in the study found different results in the United 
Arab Emirates (UAE), where the industrial sector did not affect the timeliness of financial statements. In addition to the UAE, the industrial sector is also shown to have no significant influence on the timeliness of financial reports in Vietnam (Ha et al., 2018). Differences in the results of these studies can be caused by the presence of diverse regulatory levels in each country.

Basically, each country has different factors that influence the timeliness of financial statements. This is evidenced by the existence of research that examines various factors in influencing the timeliness of financial statements between countries and shows different results (McGee, Tarangelo, and Tyler, 2009; McGee, Tyler, Tarangelo, and Igoe, 2009; McGee, Yuan, Tyler, and Tarangelo, 2009; Khasharmeh and Aljifri, 2010). In addition to the industrial sector, the share ownership factor by the government is thought to affect the timeliness of financial statements in Indonesia. The existence of state ownership in a company shows that there is a desire from the government which will then be realized in the form of regulation ( $\mathrm{Li}$ and $\mathrm{Yu}, 2018$ ). This can lead to differences in regulatory pressure on each company. The pressure then impacts on the different levels of compliance with applicable regulations, including regulations related to financial reporting deadlines.

Based on the explanation above, the phenomenon of delay in submitting financial reports often occurs in several companies in Indonesia. Submission of financial statements in a timely manner is important for every company so that the relevance value of information is maintained so that it can be used as a basis for decision making. Therefore, this study intends to examine the effect of earnings management index, state ownership, and industry sector on the timeliness of financial statements in Indonesia.

\section{RESEARCH METHOD Research Sample}

This research involved all companies listed on the IDX in 2015 to 2017 with a sample of 318 companies. The sample collection in this study applies a purposive sampling technique with the criteria in the form of companies that publish audited annual reports for 2015-2017, having a December 31 reporting date, engaged in the non-financial industry due to fundamental differences in the financial sector (Duygun et al., 2018), and provide complete information that can be accessed through the IDX website or the company's official website. The annual report is considered to have a high level of credibility (Zeghal and Ahmed, 1999) so that it is used as one of the sources of information in this study. Data related to the timeliness of financial statements is obtained through the IDX website as well as The Indonesia Capital Market Institute (TICMI).

\section{Definition and Measurement of Variable}

The dependent variable in this study is the timeliness of financial statements measured based on the number of days between the end of the accounting period, namely December 31, and the issuance of financial statements (Aktas and Kargin, 2011). On that 
date the exchange will publish the company's audited financial statements and can be accessed publicly through the IDX's official website.

The independent variables involved in this study include earnings management index, state ownership, and industrial sector. The earnings management index adopts a model developed by Serrano-Cinca et al. (2018), which is used to measure the extent to which companies engage in real earnings management activities. The earnings management index includes Days' Sales In Receivable Index (DSRI), Leverage Index (LEVI), Assets Quality Index (AQI), Sales, General, and Administrative Index (SGAI), Coefficient Variation of Sales (CvSALES), dan Coefficient Variation of Profits (CvPRO).The following is the model used in measuring earnings management index:

EMINDEX $=\sum(\mathrm{z}(\mathrm{DSRI}), \mathrm{z}(\mathrm{LEVI})$,

$$
\begin{aligned}
& \text { z(SGAI), z(AQI), } \\
& \text { z(CvSALES }), z(\text { CvPRO }))
\end{aligned}
$$

\begin{tabular}{|c|c|}
\hline & Measurement \\
\hline \multirow{2}{*}{ DSRI } & Receivables $_{\mathrm{y}} /$ Receivables $_{\mathrm{y}-1}$ \\
\hline & Sales $_{\mathrm{y}} /$ Sales $_{\mathrm{y}-1}$ \\
\hline \multirow{2}{*}{ LEVI } & Total Debt $_{\mathrm{y}} /$ Total Debt $_{\mathrm{y}-1}$ \\
\hline & $\overline{\text { Total Asset }_{\mathrm{y}}} / \overline{\text { Total Asset }_{\mathrm{y}-1}}$ \\
\hline \multirow{2}{*}{ SGAI } & General, Sales, and Administrative Expenses $/$ Sales $_{\mathrm{y}}$ \\
\hline & $\overline{\text { General, Sales, and Administrative Expenses }}$ Ex-1 $/$ Sales $_{\mathrm{y}-1}$ \\
\hline \multirow{2}{*}{ AQI } & $1-\left(\right.$ Current Asset $_{\mathrm{y}}+$ Fix Asset $_{\mathrm{y}} /$ Total Asset $\left._{\mathrm{y}}\right)$ \\
\hline & $\overline{1-\left(\text { Current Asset }_{\mathrm{y}-1}+\text { Fix Asset }_{\mathrm{y}-1} / \text { Total Asset }_{\mathrm{y}-1}\right)}$ \\
\hline $\mathrm{Cv}-$ & $\sigma\left(\right.$ Sales $_{\mathrm{y}}$, Sales $\left._{\mathrm{y}-1}\right)$ \\
\hline SALES & $\overline{\mid \mu\left(\text { Sales }_{\mathrm{y}}, \text { Sales }_{\mathrm{y}-1}\right) \mid}$ \\
\hline $\mathrm{Cv}-$ & $\sigma\left(\right.$ Net Income $_{\mathrm{y}}$, Net Income $\left._{\mathrm{y}-1}\right)$ \\
\hline PRO & $\overline{\mid \mu\left(\text { Net Income }_{y}, \text { Net Income }_{y-1}\right) \mid}$ \\
\hline
\end{tabular}

Table 1. The Indicators of Earnings Management Index

Variable of state ownership is defined as the percentage of shares held by the state for the total outstanding share capital in a company (Duygun et al., 2018). Previous research uses dummy variables as a measure in determining whether there is state ownership in a company (Rakhman, 2018). The use of percentages in measuring state ownership result in a more specific picture of the size of state ownership in influencing the effectiveness of financial reporting.

The next independent variable in this study is industrial sector, which measured using a dummy variable to separate the mining industry sector and energy sub-sector from other industrial sectors. The existence of regulations that suppress certain industries results 
in a shorter period of time for companies to get an audit signing (Bonson-Ponte et al., 2008). This can shorten the process of delivering financial statements.

Table 2. The Measurement of Variables

\begin{tabular}{ll}
\hline Variable Dependent & Measurement \\
\hline $\begin{array}{l}\text { Timeliness of Financial } \\
\text { Report (TIME) }\end{array}$ & $\begin{array}{l}\text { Number of days between December 31 } \\
\text { to the publication of financial } \\
\text { statements }\end{array}$ \\
$\begin{array}{l}\text { Earnings Management } \\
\text { Index (EMINDEX) }\end{array}$ & $\begin{array}{l}\sum(\mathrm{z}(\mathrm{DSRI}), \mathrm{z}(\mathrm{LEVI}), \mathrm{z}(\mathrm{AQI}), \mathrm{z}(\mathrm{SGAI}), \\
\mathrm{z}(\mathrm{CvSALES}), \mathrm{z}(\mathrm{CvPRO}))\end{array}$ \\
State Ownership & The number of shares owned by the \\
state & $/$ total outstanding shares \\
Industrial Sectors & Giving the score of 1 for the mining \\
(INDUSTRY) & sector and energy sub-sector, \\
& and 0 for others \\
\hline
\end{tabular}

\section{Analytical Technique}

Hypothesis testing in this study involves regression analysis of panel data with the equation model as follows:

$$
\operatorname{TIME}_{i, y}=\beta_{0}+\beta_{1} \operatorname{EMINDEX}_{i, y}+\beta_{2} \operatorname{STATEOWN}_{i, y}+\beta_{3} \operatorname{INDUSTR}_{i, y}+\varepsilon_{i, y}
$$

Notes:

$\beta_{0} \quad$ Constants

$\beta_{1}, \beta_{2}, \beta_{3} \quad$ Coefficient regression

TIME $_{\mathrm{i}, \mathrm{y}} \quad$ Timeliness of the company $\mathrm{i}$ 's financial report in the year of $\mathrm{y}$

EMINDEX $_{\mathrm{i}, \mathrm{y}} \quad$ Earnings management index of the company $\mathrm{i}$ in the year of $\mathrm{y}$

STATEOWN $_{i, y} \quad$ State ownership of the company $i$ in the year of $y$

INDUSTRY $_{i, y} \quad$ Dummy variable for the industrial sectors

$\varepsilon_{\mathrm{i}, \mathrm{y}} \quad$ Residual Error

\section{RESULTS AND DISCUSSION \\ Descriptive}

The process of collecting samples produced 318 companies during 2015 to 2017 with a total of 954 observation data. Table 3 shows the process of elimination of samples based on predetermined criteria. 
Table 3. Research Sample

\begin{tabular}{lc}
\hline Criteria & Total \\
\hline Companies listed on the IDX in 2015-2017 & 493 \\
The end date of the reporting period other & \\
than December 31 & 0 \\
Companies in the financial industry sector & $(81)$ \\
Incomplete data & $(30)$ \\
Outliers & $(64)$ \\
Total Research Sample & 318 \\
Three Periods & 954 \\
\hline Total Observation Data & 954 \\
\hline
\end{tabular}

Based on Table 4, the TIME variable shows that the average time needed by the company to submit financial statements is 88 days, with the shortest reporting time of 31 days and a maximum of 318 days. EMINDEX variable has an average value of -0.31 , with a minimum value of -8.87 and a maximum value of 14.33. Positive and negative values in the EMINDEX variable are obtained after the standardization process for each indicator that forms the earnings management index model. A positive value indicates that a company has a value for a particular indicator above the average of the indicator in question, and a negative value indicates that the value of a particular indicator is below the average value of the indicator in question. Variable STATEOWN shows an average value of $3 \%$, with a value of at least $0 \%$ in companies that are privately owned in full and a maximum value of $90 \%$ in state-owned companies. The variable INDUSTRY in this study is a dummy variable that involves the mining and energy industries with a score of one, and zero for other industries.

Table 4. Descriptive Test

\begin{tabular}{|c|c|c|c|c|}
\hline Variable & Mean & Max & Min & St.Dev \\
\hline TIME & 88.02096 & 318.0000 & 31.00000 & 18.51591 \\
\hline EMINDEX & -0.310633 & 14.33068 & -8.868963 & 1.706115 \\
\hline STATEOWN & $\begin{array}{c}0.02862 \\
5\end{array}$ & $\begin{array}{c}0.90030 \\
0\end{array}$ & 0.000000 & 0.133342 \\
\hline INDUSTRY & $\begin{array}{c}0.13207 \\
5\end{array}$ & 1.000000 & 0.000000 & 0.338750 \\
\hline
\end{tabular}

\section{Discussion}

Based on the test results in Table 5, it is known that there is a probability value of F-Statistic below 0.05, which is equal to 0.000043. This proves that the earnings management, state ownership, and industrial sector index variables partially have a significant influence on the timeliness of financial statements. In addition, the independent 
variable is said to represent the dependent variable of $2.07 \%$. This is indicated by the adjusted $\mathrm{R}^{2}$ value of 0.020703 .

Table 5. Regression Test

\begin{tabular}{ccccl}
\hline Variable & \multicolumn{1}{c}{ Coef. } & Std. Error & t-Stat. & Prob. \\
\hline C & 86.84985 & 0.861595 & 100.8013 & $0.0000^{* * *}$ \\
EMINDEX & -0.782731 & 0.313193 & -2.499198 & $0.0126^{* *}$ \\
STATEOWN & -7.334769 & 5.293714 & -1.385562 & 0.1662 \\
INDUSTRY & 8.615753 & 2.274247 & 3.788398 & $0.0002^{* * *}$ \\
R-squared & 0.023786 & & & \\
Adj. R-squared & 0.020703 & & & \\
F-statistic & 7.715693 & & & \\
Prob(F-statistic) & 0.000043 & & & \\
***,** Significant level of 1\%, 5\% & & \\
\hline
\end{tabular}

The earnings management index variable in the results of the study shows that there is a significance value below $5 \%$ of 0.0126 with a negative coefficient direction of -0.782731 . These results prove that $\mathrm{H} 1$ is accepted, namely the higher the earnings management index, the shorter the time it takes for the company to submit financial statements. This study rejects Permatasari's (2005) statement where earnings management activities slow down the financial reporting process. The existence of contractual and reporting perspectives according to Scott (2015) reflects that earnings management is a good tool for the company. In line with research by Wang, Lin, Werner, and Chang (2015), earnings management is related to equity funding activities. So that when based on a reporting perspective, where earnings management is done to influence stock market value (Scott, 2015), the company will try to deliver financial statements as quickly as possible so that the information content is maintained for various stakeholders.

The partial test results in Table 5 show that the argument for $\mathrm{H} 2$ is rejected, where state ownership does not have a significant effect on the timeliness of financial statements, both at a significant level of $1 \%$ and $5 \%$. In connection with the statements of Chen, Ghoul, Guedhami, and Wang (2017), state ownership in a company causes inefficiencies in investment which in turn results in low investor sensitivity to firm value. If investors do not have sensitivity to the value of the company, the publication of financial statements cannot influence the decision on investment.

State ownership in a company is also related to the low transparency of accounting information (Guedhami, Pittman, and Saffar, 2009) that can trigger information asymmetry or errors in decision-making. Therefore, financial statements can no longer be used as a source of information that is relevant to stakeholders. On the other hand, there is a possibility of insignificance on the influence of state ownership variables on the timeliness 
of financial statements due to the spread of data in the study sample. This study will involve additional testing to prove whether the distribution of data is the cause of this insignificance.

We prove that the classification of the mining industry sector and the energy industry sub-sector influences the timeliness of financial statements in Indonesia with a significance level of $1 \%$. However, the direction of the coefficient positively rejects $\mathrm{H} 3$ as well as the statement of Bonson-Ponte et al. (2008) where companies with high regulatory pressure will be more timely reporting it's financial information. The results of this study prove that the mining and energy industries have a longer time need to submit financial reports.

As one of the exporters of large-scale fossil fuels in the world (Kurniawan and Managi, 2018), the mining and energy industries in Indonesia have a high contribution to state revenues from export activities. In addition to the high export demand, fossil fuels such as coal, petroleum and gas are a major need for the people of Indonesia (Hasan et al., 2012). The high demand for production in the mining and energy industries is related to environmental issues, so that most of the company's operations are carried out in remote areas or far from densely populated areas. Dong, Robinson, and Xu (2017) prove that audit reports are more timely when there is a close geographical distance between the auditor and the client. Therefore, geological factors in the mining and energy industries can extend the process of presenting the company's financial statements.

\section{Additional Test}

This study involves an additional test to find out whether the data distribution in this study causes state ownership variables to have no significant influence on the timeliness of financial statements. This test involves 16 sample companies, where there is state ownership in each of these companies.

Table 6. Additional Regression Test

\begin{tabular}{crrrr}
\hline Variable & Coef & Std. Error & t-Stat & Prob. \\
\hline C & & & \multicolumn{3}{c}{$.0000^{* *}$} \\
STATEOWN & -2.43 .02993 & 12.74731 & 5.729047 & \\
R-squared & 0.000335 & 19.79879 & -0.123009 .9026 \\
Adj. R-squared & -0.021397 & & \\
F-statistic & 0.015417 & & \\
Prob(F-statistic) & 0.901725 & & \\
*** Significant level 1\% & & \\
\hline
\end{tabular}

The regression results in Table 6 prove that state ownership variables do not significantly influence the timeliness of financial statements or are consistent with the results of the research in Table 5. This shows that the occurrence of insignificance on the influence of state ownership variables is not caused by the distribution of data in the study. 
Additional test results also support the statement of Chen et al. (2017) that state ownership causes investment inefficiencies which results in a loss of investor sensitivity and a statement from Guedhami et al. (2009) where state ownership triggers information asymmetry so that information in financial statements cannot be used in determining decisions.

\section{CONCLUSION}

This study aims to determine whether there is an influence of earnings management index, state ownership, and industrial sector on the timeliness of financial reports in Indonesia for the periods of 2015-2017 involving 318 samples. The results showed that earnings management index had a significantly negative effect on the timeliness of financial statements. This is consistent with the statement of Wang et al. (2018) which proves that earnings management is related to equity funding activities, so the company will try to influence stock market value in accordance with the reporting perspective (Scott, 2015). Then, the company will accelerate the publication process to maintain the information content in the financial statements. The results of this study also prove that the mining and energy industries have a significant positive effect on the timeliness of financial statements. This happens due to the geographical area in the company's operations which in turn has an impact on the length of the company's audit process (Dong et al., 2017).

In contrast to the two factors above, state ownership in a company does not have a significant influence on the timeliness of financial statements. This can be caused by the low transparency of accounting information in companies involving state ownership (Guedhami et al., 2009). In addition, the inefficiency of investment in state-owned companies creates a loss of investor sensitivity to the market value of company shares (Chen et al., 2017). When investors do not have sensitivity to company shares, the publication of financial statements is no longer a material matter for external parties. Additional tests have also been conducted to determine whether state ownership does not have a significant influence on the timeliness of financial statements due to the distribution of data or samples in the study. Additional testing is carried out by involving certain companies that have a composition of share ownership by the state. Additional test results prove that state ownership does not have a significant influence on the timeliness of financial statements, so that insignificance does not occur due to the spread of data in the study.

\section{Recommendation}

This research involves the company's annual report, so that it is less able to reflect the company's performance in a shorter period. In addition, the earnings management index variable refers to the model formed by Serrano-Cinca et al. (2018), which does not allow measurement of the financial industry. Therefore, further research is expected to expand 
observations regarding the timeliness of financial statements by involving quarterly reports as an important source of information for investors. Further research is also expected to be able to develop research variables and involve all industrial sectors so that they can compare the characteristics of each industry in influencing the timeliness of financial statements in Indonesia.

In general, this research is expected to be able to provide implications for various parties both theoretically and practically. The company, both management and accountants, is expected to optimize the presentation of financial statements and minimize the risk of late reporting that can cause losses to the company. For regulators, this research is expected to be able to contribute as one of the considerations in evaluating applicable policies related to financial reporting, so that information in financial statements can be used by various stakeholders.

\section{REFRENCES}

Abernathy, John L., Thomas R. Kubick, \& Adi Masli. (2018). Evidence on the Relation between Managerial Ability and Financial Reporting Timeliness. International Journal of Auditing, $22(2), 1-12$.

Ajina, A., M. Laouiti, \& B.Msolli. (2016). Guiding through the Fog: Does Annual Report Readability Reveal Earnings management? Research in International Business and Finance. 38, 509-516.

Aktas, R. \& M. Kargin. (2011). Timeliness of Reporting Quality of Financial Information. International Research Journal of Finance and Economics, 63, 71-77.

Bonson-Ponte, E., C.Borrero-Dominguez, \& T. Escobar-Rodriguez. (2008). Empirical Analysis of Delays in the Signing of Audit Reports in Spain. International Journal of Auditing, 12(2), 129-140.

Braswell, M. \& R. B. Daniels. (2017). Alternative Earnings Management Techniques: What Audit Committees and Internal Auditors Should Know. The Journal of Corporate Accounting and Finance, 28(2), 45-54.

Chen, R., S. E. Ghoul, O. Guedhami, \& H. Wang. (2017). Do state and foreign ownership affect investment efficiency? Evidence from privatizations. Journal of Corporate Finance, 42, 408-421.

Chi, J. D. \& M. Gupta. (2009). Overvaluation and Earnings Management. Journal of Banking and Finance, 33, 1652-1663.

Cho, H. \& B. Song. (2017). Politically Connected Audit Committees, Earnings Quality and External Financing: Evidence from Korea. Asia-Pasific Journal of Financial Studies, 48(4), 609-634.

Christiani, I., \& Y. W.Nugrahanti. (2014). Pengaruh Kualitas Audit terhadap Manajemen Laba. Jurnal Akuntansi dan Keuangan, 16(1), 52-62.

Claessens, S. \& J. P. H. Fan. (2002). Corporate Governance in Asia: A Survey. International Review of Finance, 3(2), 71-103.

Clatworthy, M. A. and M. J. Peel. (2016). The Timeliness of UK Private Company Financial Reporting: Regulatory and Economic Influences. The British Accounting Review, 48(3), 129.

Dewi, R. R. (2005). Manajemen Laba, Kualitas Laba, dan Kredibilitas Laporan Keuangan. Media Riset Akuntansi, Auditing dan Informasi, 5(1), 25-39. 
Dong, B., D. Robinson, \& L. E.Xu.(2018). Auditor-Client Geographic Proximity and Audit Report Timeliness. Advances in Accounting,.40, 11-19.

Dutu, R. (2016). Challenger and Policies in Indonesia's Energy Sector.Energy Policy, 98, 513-519.

Duygun, M., Y. Guney, \& A. Moin. (2018). Dividend Policy of Indonesian Listed Firms: The Role of Families and State. Economic Modelling, 75, 336-354.

Dyer, J. C. IV. \& A. J. McHugh. (1975). The Timeliness of The Australian Annual Report. Journal of Accounting Research, 13(2), 204-219.

Financial Accounting Standards Board. (2010). Statement of Financial Accounting Concepts No. 8 Conceptual Framework for Financial Reporting. https://www.fasb.org, accessed 31 December 2018.

Franedya, R. 02 July (2018). Tak Sampaikan Lapkeu 2017 Auditan, BEI Suspensi 10 Saham. https://www.cnbcindonesia.com, accessed 30 December 2018.

Gavious, I., E. Segev, \& R. Yosef. (2012). Female Directors and Earnings Management in HighTechnology Firms. Pasific Accounting Review, 24(1), 4-32.

Ghafran, C. \& S.Yasmin. (2017). Audit Committee Chair and Financial Reporting Timeliness: A Focus on Financial, Experimental, and Monitoring Expertise. International Journal of Auditing, 22(1), 13-24.

Guedhami, O., J. A. Pittman, \& W.Saffar. (2009). Auditor Choice in Privatized Firms: Empirical Evidence on the Role of State and Foreign Owners. Journal of Accounting and Economics, 48 (2-3), 151-171.

Gull, A. A., M. Nekhili, H. Nagati, \& T.Chtioui. (2018). Beyond Gender Diversity: How Specific Attributes of Female Directors Affect Earnings Management. The British Accounting Review, 50(3), 255-274.

Ha, H. T. V., D. N. Hung, \& N. T. T. Phuong. (2018). The Study of Factors Affecting the Timeliness of Financial Reports: The Experiments on Listed Companies in Vietnam. Asia Economic and Financial Review, 8(2), 294-307.

Hasan, M. H. et al. (2012). A Review on the Pattern of Electricity Generation and Emission in Indonesia from 1987 to 2009. Renewable and Sustainable Energy Review, 16(5), 32063219.

Healy, P. M. \& J. M. Wahlen. (1999). A Review of the Earnings Management Literature and Its Implications for Standard Setting. Accounting Horizons, 13(4), 365-383.

Jensen, M. C. \& W. H. Meckling. (1976). Theory Of The Firm: Managerial Behavior, Agency Cost And Ownership Structure. Journal of Financial Economics,. 3(4), 305-360.

Jogiyanto, H. (2013). Teori Portofolio dan Analisis Investasi. Edisi Kedelapan. Yogyakarta: BPFE.

Ketua Dewan Komidioner Otoritas Jasa Keuangan. Peraturan Otoritas Jasa Keuangan (POJK) No. 29 / POJK. 04/2016 tentang Laporan Tahunan Emiten atau Perusahaan Publik. https://www.ojk.go.id, accessed 25 December 2018.

Khasharmeh, H. A. \& K.Aljifri. (2010). The Timeliness of Annual Reports in Bahrain and the United Arab Emirates: An Empirical Comparative Study. The International Journal of Business and Finance Research, 4(1), 51-71.

Krishnan, G. V. \& L. M. Parsons. (2008). Getting to the Bottom Line: An Exploration of Gender and Earnings Quality. Journal of Business Ethics, 78(1), 65-76.

Kurniawan, R. \& S.Managi.2018. Coal Consumption, Urbanization, and Trade Openness Linkage in Indonesia. Energy Policy, 121, 576-583.

Kusuma, H. (2006). Dampak Manajemen Laba terhadap Relevansi Informasi Akuntansi: Bukti Empiris dari Indonesia. Jurnal Akuntansi dan Keuangan, 8(1), 1-12.

Li, J. \& L. Yu. (2018). How Does State-owned Shares Affect Double Externalities and Industrial Performance: Evidence from China's Exhaustible Resources Industry. Journal of Cleaner Production, 176, 920-928. 
Lie, N. Y. S. (2012). Faktor-Faktor yang Mempengaruhi Ketepatan Waktu Penyampaian Laporan Keuangan pada Perusahaan Pertambangan di BEI periode 2008-2010. Jurnal Ilmiah Mahasiswa Akuntansi,1(1), 27-32.

McGee, R. W., T. Tarangelo, \& M. Tyler. (2009). Chapter 15 The Timeliness of Financial Reporting: A Comparative Study of Companies in Russia and the USA. Corporate Governance in Transition Economics, 157-163.

McGee, R. W., M. Tyler, T. Tarangelo, \& D. N.Igoe. (2009). Chapter 16 the Timeliness of Financial Reporting: A Comparative Study of Companies in Russia and the European Union. Corporate Governance in Transition Economics, 165-171.

McGee, R. W., X. Yuan, M. Tyler, \& T.Tarangelo. (2009). Chapter 17 The Timeliness of Financial Reporting: A Comparative Study of People's Republic of China and Russia. Corporate Governance in Transition Economics, 173-179.

Melani, A. (2016). Belum Sampaikan Laporan Tahunan, BEI Beri Sanksi ke 63 Emiten. http://www.liputan6.com, accessed 24 March 2018.

Menteri Hukum dan Hak Asasi Republik Indonesia. (2012). Peraturan Pemerintah Republik Indonesia Nomor 24 Tahun 2012 tentang Perubahan Atas Peraturan Pemerintah Nomor 23 Tahun 2010 tentang Pelaksanaan Kegiatan Usaha Pertambangan Mineral Dan Batubara. http://eiti.ekon.go.id, accessed 7 January 2019.

Menteri Hukumdan Hak Asasi Republik Indonesia. (2015). Peraturan Menteri Pertanian Republik Indonesia Nomor: 26/Permentan/ Hk.140/4/2015 tentang Syarat, Tata Cara Dan Standar Operasional Prosedur Pemberian Rekomendasi Teknis Izin Usaha Di Bidang Pertanian Dalam Rangka Penanaman Modal. https://www.bkpm.go.id, accessed 7 January 2019.

Permatasari, I. (2005). Manajemen Laba dan Status Keterlambatan Perusahaan dalam Menyampaikan Laporan Keuangan Tahunan. Jurnal Akuntansi dan Keuangan Indonesia, 2(2), 49-72.

Pratama, B. \& A. S. Adiwibowo. (2014). Analisis Faktor-Faktor yang Mempengaruhi Audit Delay dan Timeliness pada Perusahaan Publik di Indonesia (Studi Empiris pada Perusahaan yang Terdaftar Secara Konsisten di LQ45 pada Bursa Efek Indonesia). Diponegoro Journal of Accounting, 3(2), 1-12.

Purwanto, W. W.et al. (2016). Status and Outlook of Natural Gas Industry Development in Indonesia. Journal of Natural Gas Science and Engineering, 29, 55-65.

Rakhman, F. (2018). Can Partially Privatized SOEs Outperform Fully Private Firms? Evidence from Indonesia. Research in International Business and Finance, 45, 285-292.

Scott, W. R. (2015). Financial Accounting Theory. Seventh Edition. United States: Pearson.

Sekretaris Negara Republik Indonesia. (2003). Undang-Undang Republik Indonesia Nomor 19 Tahun 2003 Tentang Badan Usaha Milik Negara. https://www.komisiinformasi.go.id, accessed 7 January 2019.

Serrano-Cinca, C., B. Gutierrez-Nieto, \& M. Bernate-Valbuena. (2018). The Use of Accounting Anomalies Indicators to Predict Business Failure. European Management Journal, Articles in Press.

Sugianto, D. 3 July (2017). 17 Saham Disuspensi Sekaligus, dari BTEL hingga ENRG. https://finance.detik.com, accessed 24 March 2018.

Suharli, M. \& S. S. Harahap. (2008). Timeliness Laporan Keuangan di Indonesia (Studi Empiris Terhadap Emiten Bursa Efek Jakarta). Media Riset Akuntansi, Auditing, dan Informasi, 8(2), 97-116.

Suripto, B. (2013). Manajemen Labadan Manajemen Impresi dalam Laporan Tahunan: Penelitian Strategi Pengungkapan Perusahaan. Jurnal Akuntansi dan Keuangan Indonesia, 10(1), 4059. 
Wang, T. S., Y. M. Lin, E. M. Werner., \& H. Chang. (2018). The relationship between external financing activities and earnings management: Evidence from enterprise risk management. International Review of Economics and Finance, 58, 312-329.

Wells, T. D. \& C. Sevilla. (2001). Forming a Dialogue with Academia: Industry Requirements versus Academic Programs. Information Systems Management, 18(1), 80-83.

Widyawati, A. A. \& V. Anggraita. (2013). Pengaruh Kovergensi, Kompleksitas Akuntansi, dan Probabilitas Kebangkrutan terhadap Timeliness dan Manajemen Laba. Jurnal Akuntansi dan Auditing Indonesia, 17(2), 135-155. 